small when considering the overall experimental period: those observed during early growth were compensated for during the finishing period.

No effect was obtained by adding lysine to a wheat based diet containing $\mathrm{I} 5$ per cent crude protein, the results recorded with the non supplemented diet being similar.

Use of lucerne meal ( $2 \%$ ) as a partial protein supplementation led to good growth performances during the whole period studied as compared with those obtained at a protein level of 16.5 per cent, with a diet without lucerne meal. In the case of diets containing is per cent protein and supplemented with lysine, the results were equivalent to those obtained with the former protein level when taking into account the overall experimental period because of a relative compensation of the growth rate during the finishing period.

There was a negative effect on feed conversion ratio and carcass yield in direct correlation with the energy concentration of the diet.

\title{
Effect of the protein level on growth performance of finishing pigs
}

\author{
Y. HENRY \\ Station de Recherches sur l'Élevage des Porcs, \\ I.N.R.A.-C.N.R.Z., 78350 Jouy-en-Josas (France)
}

The present study was conducted in order to evaluate the possibilities of reducing the protein level in the diet of finishing pigs under an optimal balance between essential amino acids. Two experiments were performed, with individually and group-fed Large white pigs, between $5^{\circ}$ and $100 \mathrm{~kg}$ final body weight. Both castrated moles and females were given diets containing I 7, I 5, 13 and I $\mathrm{I}$ per cent crude protein, with or whitout supplementary lysine and tryptophan, under a liberal feeding schedule. The reduction of the protein content in this type of diet to a level compatible with optimal growth performance was obtained with a rather low supplementation in lysine and without any addition of tryptophan, due to the satisfactory balance betwen the dietary essential aminoacids. The minimal level of undifferenciated protein. after the requirements of essential aminoacids had been met, without unfavourable effects on growth performance and carcass grading, was 12 per cent in castrated males and I $^{-1} 4$ per cent $^{-1}$ in females. corresponding to $3^{6}$ and $4^{0-4^{2}} \mathrm{~g}$ crude protein per Mcal digestible energy, respectively.

\section{Energy and protein value of different varieties of peas (Pisum sativum L.) for the pig}

\author{
D. BOURDON, Janine JUNG et J. M. PEREZ
}

Station de Recherches sur l'Élevage des Pores, I.N.R.A.C.N.R.Z., $7835^{\circ}$ Jouy-en-Josas (France)

Five digestibility trials were conducted in order to estimate the nutritive value of various types of peas (Pisum sativum L.) for the growing pig. Two wrinkled varieties (Lincoln and Frogel) and three smooth ones (Starcovert, Frimas and A 86), were tested. The energy value of the pea averaged that of maize, i.e. 3,940 Kcal digestible energy (or 3,760 Kcal metabolisable energy) per kg dry matter and the apparent digestibility coefficient of the energy represented 88.8 per cent. The apparent digestibility of crude protein $(84.2 \%)$ was slightly lower than that of soya-bean meal protein $(89 \%)$. The amino-acid composition of the seeds determined in this study indicates that the protein balance of peas is good, especially with respect to lysine $(7.4 \mathrm{~g}$ for $16 \mathrm{~g}$ nitrogen). 